\title{
Listy do redakcji
}

\section{Oświadczenie}

Magdalena Piekara, Wacław Forajter,

Bartłomiej Szleszyński

Y niżej podpisani stanowczo protestujemy przeciwko tezom dra hab. prof. UKW Macieja Glogera, zamieszczonym we wstępie do tomu Między pozytywizmem inacjonalizmem. Przemiany kultury polskiej w latach 1886-1918. W 2016 roku wzięliśmy udział w identycznie zatytułowanej konferencji w Sopocie, licząc na stricte naukowy, obiektywny kształt zarówno obrad, jak i późniejszej publikacji. Jak jednak wynika z przedmowy do książki, zamiar organizatora był wyraźnie podporządkowany celom ideologicznym. Maciej Gloger pisze tam m.in. o liberalnych poglądach badaczy pozytywizmu, wpływających na stereotypowy ogląd relacji między „pozytywizmem” i „nacjonalizmem” czy o „ewolucji ideowej pozytywistów ku narodowej demokracji i nowoczesnej świadomości narodowej”. Wspomina również o „antypolskiej działalności organizacji i elit żydowskich" w okresie I wojny światowej, co wydaje się nam niezdrowym poszukiwaniem sensacji w zakresie tematu rzetelnie opracowanego przez historyków, kulturoznawców i polonistów, a także dowodzi niewielkiej znajomości faktów historycznych. 
Konstruując tak zorientowany wstęp, redaktor publikacji wpisał nas jako autorów zamieszczonych tam tekstów w ramy określonego projektu światopoglądowego. Użyte w przedmowie Glogera kwantyfikatory zacierają także złożoność obrazu i sugerują bezpośredni akces wszystkich pozytywistów do endecji, manifestacyjną antypolskość wpływowych osób pochodzenia żydowskiego w ogóle czy nieuzasadnione uprzedzenia współczesnych historyków literatury do problematyki polskiego ruchu narodowego z początków jego istnienia.

Nasza niezgoda jest przede wszystkim głosem skierowanym przeciwko upolitycznieniu nauki, dotyczy badań prowadzonych "pod dyktando" ideologiczne, a tym samym wiążących się z dość prostym, jakże powszechnym np. w czasach socrealizmu, podziałem na badania "słuszne" i „niesłuszne" pod względem politycznym.

dr hab. Magdalena Piekara (UŚ)

dr hab. Wacław Forajter (UŚ)

dr Bartłomiej Szleszyński (IBL PAN) 